\title{
NEW RESULTS ABOUT HARDY-TYPE INEQUALITY
}

\author{
Kristina KRUlić HimmelReich, Josip PeČARIĆ, \\ DORA POKAZ AND MARJAN PRALJAK
}

Abstract. We give a Levinson type generalization of Hardy's inequality with convex functions replaced by 3-convex functions at a point. Several results and examples are provided, both onedimensional and multidimensional.

Mathematics subject classification (2010): Primary 26D10; Secondary 26D15. Keywords and phrases: Hardy's inequality, convex function, 3 -convex function.

\section{REFERENCES}

[1] M. Abramowitz And I. A. Stegun (Eds), Handbook of Mathematical Functions with Formulas, Graphs and Mathematical Tables, $9^{\text {th }}$ printing, Dover, New York, 1972.

[2] I. A. BAloch, J. PeČARIĆ ANd M. PraljaK, Generalization of Levinson's inequality, J. Math. Inequal., to appear.

[3] Y. Bicheng, Z. Zhuohua And L. Debnath, On new generalizations of Hardy's integral inequality, J. Math. Anal. Appl. 217, 1 (1998), 321-327.

[4] A. ČIŽmešIJA And J. PeČArić, Some new generalizations of inequalities of Hardy and LevinCochran-Lee, Bull. Aust. Math. Soc. 63 (2001), no. 1, 105-113.

[5] E. K. Godunova, Generalization of a two-parameter Hilbert inequality, (Russian) Izv. Vysš. Učebn. Zaved. Matematika 1967 54, 1 (1967), 35-39.

[6] G. H. HARDY, Note on a theorem of Hilbert, Math. Z. 6 (1920), 314-317.

[7] G. H. HARDY, Notes on some points in the integral calculus, LX. An inequality between integrals, Messenger of Math. 54 (1925), 150-156.

[8] G. H. HARDY, Notes on some points in the integral calculus LXIV, Messenger of Math. 57 (1928), $12-16$.

[9] K. Knopp, Über Reihen mit positiven Gliedern, J. London Math. Soc. 3 (1928), 205-211.

[10] K. Krulić, J. PeČArić And L.-E. Persson, Some new Hardy type inequalities with general kernels, Math. Inequal. Appl. 12 (2009), 473-485.

[11] K. Krulić Himmelreich, J. PeČArić And D. PokAZ, Inequalities of Hardy and Jensen, Element, Zagreb, 2013.

[12] J. PeČarić, F. Proschan And Y. L. Tong, Convex Functions, Partial Orderings and Statistical Applications, Academic Press, San Diego, 1992.

[13] J. PeČArić, M. PraljaK AND A. WitKows Ki, Generalized Levinson's inequality and exponential convexity, Opuscula Math. 35, 1 (2015),397-410. 